\title{
Kapasitas Vital Paru Berkorelasi Positif dengan Kemampuan Tahan Nafas pada Laki-Laki Usia 19-25 Tahun
}

Kukuh Pambuka Putra ${ }^{a}$, Rizal Putra Pratama ${ }^{\text {b }}$, Kristiawan Prasetyo Agung Nugrohoc*

a,b,cFakultas Kedokteran dan Ilmu Kesehatan, Universitas Kristen Satya Wacana, Jl. Kartini 11A Salatiga, 50711 Jawa Tengah, Indonesia.

Correspondence: kukuh.pambuka@outlook.com

Received: 03 Apr 2020 Accepted: 26 Apr 2020 Published: 29 Apr 2020

\begin{abstract}
Freediving is a diving activity without any breathing equipments. The durations of the dive activity depend on ability to hold breath (apnea). The ability of apnea may be affected by lung vital capacity. The purpose of this study is to find out the relationship between vital lung capacity and apnea duration in 30 males 19-25 years old. Vital lung capacity measured using spirometer and the duration of apnea measured using stopwatch in swimming pool. Data analyzed using 1-tailed pearson correlation test. The result shows that there is a correlation $(p<0,05)$ between vital lung capacity and the duration of apnea. The correlation coeficient is 0,743 that means this is a strong positive correlation between the two variables.
\end{abstract}

Keywords: Apnea; Diving; Freedive; Lung; Vital Capacity.

\begin{abstract}
Abstrak
Freediving adalah aktivitas menyelam tanpa alat bantu pernapasan. Durasi aktivitas menyelam tergantung pada durasi menahan nafas (apnea). Durasi apnea diduga dipengaruhi oleh kapasitas vital paru. Tujuan dari penelitian ini adalah untuk mengetahui korelasi antara kapasitas vital paru dan durasi apnea pada 30 pria berusia 19-25 tahun. Kapasitas paru vital diukur menggunakan spirometer dan durasi apnea diukur menggunakan stopwatch di kolam renang. Data dianalisis menggunakan uji korelasi pearson 1 arah. Hasil penelitian menunjukkan bahwa ada korelasi $(p<0,05)$ antara kapasitas paru vital dan durasi apnea. Koefisien korelasi adalah 0,743 yang berarti ini adalah korelasi positif yang kuat antar kedua variabel.
\end{abstract}

Kata kunci: Apnea; Selam; Selam Bebas; Paru; Kapasitas Vital

\section{Pendahuluan}

Selam adalah suatu aktivitas fisik yang dilakukan di bawah permukaan air, yang sudah dikenal sejak beberapa abad yang lalu (Bosco, Rizzato, Moon, \& Camporesi, 2018). Terdapat dua jenis selam, yaitu selam bebas (Freediving) yang dilakukan tanpa alat bantu pernafasan, hanya menggunakan alat bantu penglihatan (masker selam) dan alat bantu gerak berupa fin (AIDA-International, 1992; Christen, 2015); dan selam yang menggunakan satu set alat bantu pernafasan bawah air yang lengkap yaitu SCUBA (Self Contained Underwater Breathing Apparatus).

Freediving dapat dikategorikan olahraga rekreasi dan olahraga ekstrim. Freediving untuk rekreasi biasanya dilakukan pada kedalaman yang tidak terlalu dalam dan dengan durasi waktu yang tidak terlalu lama. Selain itu, Freediving juga termasuk ke dalam kategori olahraga ekstrim karena penyelam tidak 
menggunakan alat bantu pernafasan dan penyelam menahan nafas selama durasi tertentu. Capaian dalam olahraga freedive umumnya adalah kedalaman penyelaman atau durasi penyelaman (Ostrowski et al., 2012).

Biasanya, lamanya penyelaman tergantung pada kemampuan penyelam dalam menahan nafas (apnea). Istilah apnea (henti nafas) adalah kondisi berhentinya pernafasan selama beberapa waktu, tetapi dalam dunia selam, apnea dilakukan secara sengaja dalam jangka waktu yang relatif lama (Erez, 2016). Namun demikian secara fisiologis semakin lama seseorang menahan nafas di bawah permukaan air, semakin besar pula risiko fisiologis yang mungkin terjadi, salah satunya adalah kekurangan oksigen atau hipoksia (Lindholm \& Lundgren, 2009).

Hipoksia adalah kekurangan oksigen pada berbagai organ tubuh. Saat paru berhenti mengambil udara, maka jumlah oksigen dalam darah akan berkurang yang kemudian mempengaruhi suplai oksigen ke organ-organ tubuh, sehingga berpotensi mengakibatkan gangguan fungsi organ dan bahkan kerusakan berbagai organ tubuh (Cafaro, 1960; Schödel \& Ratcliffe, 2019). Dampak paling fatal adalah ketika otak tidak menerima suplai oksigen dalam beberapa waktu maka akan dapat menyebabkan kehilangan kesadaran, kerusakan otak yang irreversible dan bahkan kematian (Butler, 2005; Perlman, 2007). Salah satu risiko yang sering terjadi pada penyelam ketika melakukan freedive adalah kehilangan kesadaran (blackout) yang disebabkan karena otak kehabisan suplai oksigen (bypoxic blackout) (Pearn, Franklin, \& Peden, 2015). Ketika seorang penyelam turun ke bawah permukaan air, penyelam akan mulai menahan nafas. Lamanya penyelaman tergantung dari seberapa lama penyelam dapat bertahan di bawah air dalam kondisi menahan nafas, yang dipercaya berkorelasi dengan seberapa banyak paru dapat menampung udara.

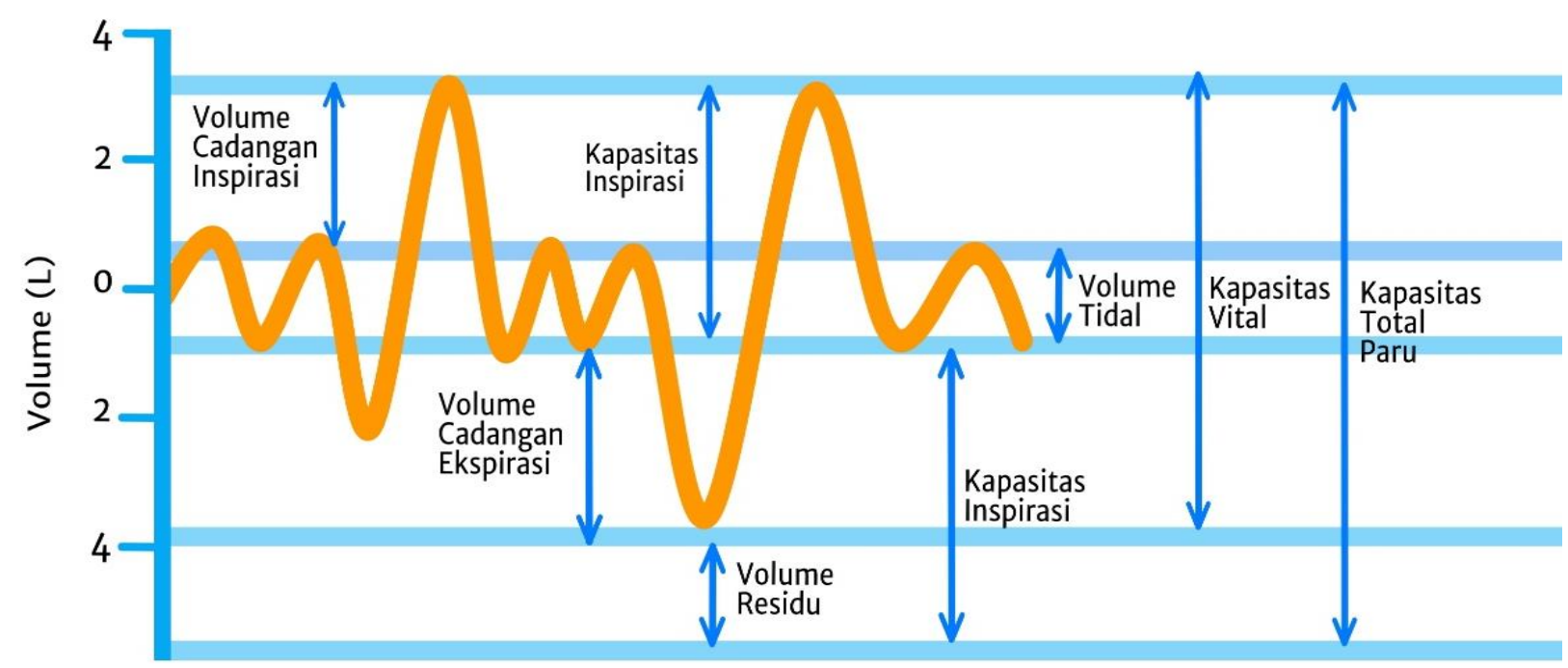

\section{Gambar 1. Diagram Kapasitas Paru (Sewa \& Ong, 2014)}

Kapasitas paru merupakan faktor penting dalam freediving. Kapasitas paru adalah jumlah dua atau lebih volume paru. Volume paru adalah volume udara yang bisa ditampung di dalam paru. Volume dan kapasitas paru terdiri dari: Volume Tidal (VT) merupakan volume udara yang dihirup (inspirasi) dan dihembuskan (ekspirasi) setiap kali melakukan pernafasan normal atau pernafasan ketika aktivitas biasa. Volume Cadangan Inspirasi (VCI) adalah volume maksimal udara yang bisa dihirup dari tingkat akhir inspirasi sampai paru tidak dapat menarik nafas lagi, Volume Cadangan Ekspirasi (VCE) merupakan maksimal volume udara yang bisa dihembuskan dari posisi akhir ekspirasi hingga paru tidak dapat lagi menghembuskan nafas. Volume Residu (VR) adalah jumlah (volume) udara yang terperangkap dalam paru bahkan sesudah dilakukan ekspirasi secara maksimal. Kapasitas Inspirasi (KI) 
adalah volume tidal yang ditambah volume cadangan inspirasi. Kapasitas Fungsional Residu (KFR) adalah volume cadangan ekspirasi ditambah volume residu. Kapasitas Vital (KV) adalah volume tidal ditambah volume cadangan ekspirasi dan volume cadangan inspirasi. Sedangkan Kapasitas Total Paru (KTP) adalah jumlah seluruh volume paru (Guyton \& Hall, 2006; Sherwood, 2015).

Kapasitas vital paru diduga memiliki korelasi positif dengan kemampuan untuk menahan nafas (apnea). Apabila volume udara yang dapat ditampung paru semakin besar, maka semakin besar pula cadangan oksigen tersedia untuk diedarkan ke seluruh tubuh dan memungkinkan metabolisme aerobik (metabolisme tubuh menggunakan $\mathrm{O}_{2}$ menjadi ATP) dapat terjadi lebih lama. Oleh karena itu perlu dipelajari apakah semakin besar kapasitas vital seseorang, semakin lama pula durasi menahan nafas.

Penelitian ini bertujuan untuk mempelajari korelasi kapasitas vital paru terhadap kemampuan apnea yang diwakili oleh durasi apnea. Hasil penelitian ini diharapkan dapat menjadi acuan bagi penyelam bebas (freediver) dalam mempersiapkan diri sebelum melakukan suatu sesi penyelaman. Diharapkan pula dapat menjadi pertimbangan dalam penyusunan program latihan selam bagi atlet selam yang membutuhkan durasi apnea lebih lama. Hipotesis dalam penelitian ini adalah semakin besar kapasitas vital paru maka semakin lama durasi apnea.

\section{Metode Penelitian}

Penelitian ini merupakan studi analitik observasional yang mempelajari korelasi antara kapasitas vital paru dengan kemampuan apnea. Instrumen untuk mengukur kapasitas vital paru dalam penelitian ini adalah spirometer (Morris, 1976) dan alat yang digunakan untuk mengukur durasi apnea adalah stopwatch. Spirometer adalah alat yang digunakan untuk mengukur volume udara (Liter) yang keluar dan masuk paru. Stopwatch digunakan untuk mengukur waktu menahan nafas (apnea) dengan satuan detik.

Cara penggunaan spirometer yaitu dengan bernafas menggunakan mulut melalui mouthpiece dengan posisi hidung ditutup (Sewa \& Ong, 2014). Spirometer dihubungkan ke komputer melalaui sambungan USB. Aktivitas spirometer dipantau melalui komputer hingga mendapatkan angka hasil dalam satuan Liter. Pengukuran kapasitas vital dilakukan sebanyak 3 kali pengulangan setiap subjek dan diambil angka yang terbesar.

Cara mengukur kemampuan apnea yaitu dengan cara menghitung seberapa lama subjek dapat menahan nafas di bawah permukaan air. Penghitungan dimulai ketika subjek mulai menarik nafas panjang, kemudian masuk ke bawah permukaan air hingga kembali naik ke permukaan air. Pengukuran kemampuan apnea dilakukan di kolam yang dangkal dengan kedalaman 1 meter, dengan posisi tubuh jongkok tidak bergerak untuk meminimalkan aktivitas otot yang berdampak pada konsumsi oksigen di otot. Apabila subjek merasa tidak kuat, subjek dapat berdiri atau dapat keluar dari dalam air. Sebelum melakukan pengukuran durasi apnea, subjek diukur saturasi oksigen terlebih dahulu menggunakan oksimeter untuk mengetahui kadar oksigen di dalam pembuluh kapiler subjek dan memastikan subjek tidak memiliki masalah dalam distribusi oksigen dalam tubuhnya. Pengukuran durasi apnea dilakukan sebanyak 3 kali pengulangan setiap subjek dan diambil angka yang terbesar.

Subjek dalam penelitian ini adalah 30 orang laki-laki yang tidak terlatih. Subjek ditentukan dengan metode purposive sampling. Kriteria inklusi dalam penelitian ini adalah berjenis kelamin laki-laki, usia 1925 tahun, tinggi badan 155-180 cm, berat badan berkisar 50-90 kg, lingkar dada 75-120 cm, dalam keadaan sehat, tidak sedang mengonsumsi obat dan bersedia untuk menjadi subjek dalam penelitian ini. Kriteria eksklusi yaitu memiliki gangguan sistem kardio dan atau respirasi serta tidak bersedia untuk menjadi subjek penelitian ini. Subjek yang sesuai dengan kriteria, kemudian diukur kapasitas parunya menggunakan spirometer. Pengukuran kapasitas vital paru dilakukan dengan 3 kali pengulangan, hal 
ini dilakukan untuk mencari hasil yang terbaik dari pengukuran kapasitas vital paru. Pengukuran dilakukan di Laboratorium FKIK UKSW.

Subjek yang telah diukur kapasitas vital parunya, kemudian diukur kemampuan menahan nafasnya (apnea). Risiko yang mungkin terjadi dalam pengukuran ini adalah hipoksia, juga mungkin subjek akan mengalami kelelahan baik sebelum maupun sesudah tes yang diberikan. Untuk menghindari risiko tersebut, sebelum melakukan pengukuran, subjek diukur saturasi oksigennya terlebih dahulu menggunakan oksimeter untuk mengetahui kadar oksigen dalam kapiler subjek. Pengukuran kemampuan apnea dilakukan dengan 3 kali pengulangan, untuk mencari hasil yang terbaik dari pengukuran waktu penyelaman. Pengukuran dilakukan di kolam renang Kalitaman Kota Salatiga. Seluruh protokol dalam penelitian ini telah dinyatakan Laik Etik oleh Komisi Etik Penelitian, Fakultas Kedokteran \& Ilmu Kesehatan UKSW.

Uji normalitas data dilakukan untuk mencari tahu normalitas distribusi data. Uji normalitas yang dilakukan adalah uji normalitas berdasarkan Shapiro-Wilk karena jumlah subjek penelitian ini kurang atau sama dengan 50 orang. Kaidah untuk mengetahui normalitas distribusi data adalah bahwa bila nilai $\mathrm{p}<0,05$ maka dikatakan data tersebut tidak terdistribusi normal, namun bila nilai $\mathrm{p}>0,05$ maka data tersebut dapat dikatakan berdistribusi normal. Dilanjutkan dengan Uji korelasi satu arah (1-tailed) variabel kapasitas vital paru terhadap durasi apnea. Kaidah yang digunakan mengetahui korelasi antar kedua variabel adalah bila nilai $\mathrm{p}<0,05$ maka berarti ada korelasi antara kapasitas vital dengan durasi apnea, sebaliknya bila nilai nilai $\mathrm{p}>0,05$ maka berarti tidak ada korelasi antara kapasitas vital dengan durasi apnea. Koefisien korelasi -1 sampai 1 menentukan arah dan kekuatan korelasi antar variabel.

\section{Hasil}

Hasil dari pengukuran variabel kapasitas vital paru dan durasi apnea subjek tercantum dalam Tabel 1. Rerata kapasitas vital paru dari para subjek sebesar 3.816 \pm 0.61 liter dengan nilai maksimum sebesar 4.87 liter dan nilai minimum sebesar 2.75 liter. Rerata durasi apnea para subjek sebesar 35.28土15.15 detik dengan nilai maksimum sebesar 70.56 detik dan nilai minimum 13.60 detik.

Tabel 1. Data Hasil Pengukuran Kapasitas Vital Paru dan Durasi Apnea

\begin{tabular}{|c|c|c|}
\hline & $\begin{array}{l}\text { Kapasitas Vital } \\
\text { Paru (Liter) }\end{array}$ & $\begin{array}{l}\text { Durasi Apnea } \\
\text { (Detik) }\end{array}$ \\
\hline Rerata & $3.816 \pm 0.61$ & $35.28 \pm 15.15$ \\
\hline Maksimum & 4.87 & 70.56 \\
\hline Minimum & 2.75 & 13.6 \\
\hline
\end{tabular}

Tabel 2. Hasil Uji Normalitas Pengukuran Kapasitas Vital Paru dan Durasi Apnea

\begin{tabular}{llll}
\hline \multirow{2}{*}{ Normality Test } & \multicolumn{3}{l}{ Shapiro-Wilk } \\
\cline { 2 - 4 } & Statistic & df & Sig. \\
\hline Durasi Apnea & 0.952 & 30 & 0.192 \\
Kapasitas Vital & 0.961 & 30 & 0.331 \\
\hline
\end{tabular}


Tabel 3. Hasil Uji Korelasi Pearson untuk Pengukuran Kapasitas Vital dan Durasi Apnea

\begin{tabular}{llll}
\hline & & Durasi Apnea & Kapasitas Vital \\
\hline \multirow{2}{*}{ Durasi } & P. Correlation & 1 & 0,743 \\
Apnea & Sig. (1-tailed) & & 0,000 \\
& N & 30 & 30 \\
\hline \multirow{2}{*}{ Kapasitas } & P. Correlation & 0,743 & 1 \\
Vital & Sig. (1-tailed) & 0,000 & \\
& N & 30 & 30 \\
\hline
\end{tabular}

Hasil Uji Normalitas data dengan Uji Shapiro-Wilk pada Tabel 2 menyatakan bahwa variabel durasi apnea $(\mathrm{p}=0.192)$ dan kapasitas vital paru $(\mathrm{p}=0.331)$ memiliki $\mathrm{p}>0.05$, dapat disimpulkan bahwa data kedua variabel tersebut berdistribusi normal. Uji Korelasi Pearson satu arah (1-tailed) pada variabel kapasitas vital paru terhadap durasi apnea pada Tabel 3 menyatakan bahwa kedua variabel tersebut memiliki korelasi karena nilai $\mathrm{p}=0.000(\mathrm{p}<0,05)$ dengan koefisien korelasi sebesar 0.743. Menurut M. Sopiyudin Dahlan, nilai koefisien korelasi (r) sebesar 0.7 termasuk ke dalam kategori relasi / korelasi yang kuat (Dahlan, 2015).

\section{Pembahasan}

Kapasitas vital paru merupakan salah satu variabel yang paling penting pada dalam kemampuan apnea. Hasil uji korelasi antara durasi apnea dan kapasitas vital pada penelitian ini termasuk ke dalam kategori korelasi positif yang kuat. Orang yang memiliki kapasitas paru yang besar dapat menahan nafas lebih lama dibandingkan dengan orang yang memiliki kapasitas paru yang lebih kecil. Semakin banyak oksigen yang dapat ditampung oleh paru, maka semakin banyak pula cadangan oksigen yang tersedia untuk diedarkan ke seluruh tubuh.

Metabolisme biasanya memerlukan sekitar 25\% dari oksigen untuk aktivitas otot; metabolisme menghasilkan panas dan mendukung fungsi metabolisme lainnya. Jika oksigen tidak tersuplai dengan baik akan menyebabkan hipoksia (kekurangan oksigen) yang dapat berujung pada gangguan metabolisme bahkan kegagalan fungsi organ (Lindholm \& Lundgren, 2009). Penyelam yang memiliki kapasitas vital rendah mungkin lebih berpotensi untuk mengalami bypoxic blackout. Selain bypoxic blackout, resiko lain yang mungkin dialami oleh penyelam adalah penyakit dekompresi (akibat perubahan tekanan air) (Butler, 2005; Guyton \& Hall, 2006; McArdle, Katch, \& Katch, 2009).

Bagi penyelam, pemahaman terhadap kapasitas vital paru merupakan hal yang vital untuk diperhatikan agar dapat meminimalkan atau bahkan terhindar dari risiko hipoksia. Hipoksia dapat menyebabkan penyelam mengalami gangguan fisiologis berat, karena tubuh kekurangan oksigen akut yang dapat menyebabkan kehilangan kesadaran karena tidak adanya suplai oksigen dalam waktu lama (Schödel \& Ratcliffe, 2019). Bagi penyelam yang memiliki kapasitas paru yang rendah diharapkan untuk berlatih demi menambah kapasitas vital paru sebelum melakukan penyelaman freedive.

Penyelam dapat menambah kapasitas vital parunya dengan melakukan latihan fisik yang berhubungan dengan metabolisme aerobik. Metabolisme aerobik adalah metabolisme yang menggunakan oksigen untuk menghasilkan ATP (McArdle et al., 2009). Aktivitas fisik aerobik adalah aktivitas fisik yang bergantung pada ketersediaan oksigen sebagai bahan untuk proses metabolisme glukosa, sehingga aktivitas yang dilakukan juga bergantung pada kerja optimal organ-organ sistem pernafasan dan kardio seperti jantung, paru dan pembuluh darah dalam distribusi oksigen demi proses metabolisme dapat terjadi dengan optimal (Giriwijoyo, 2017). Melalui upaya latihan aerobik, maka kekuatan otot intercosta external pada tulang rusuk akan semakin meningkat, semakin kuat untuk menarik rusuk dan 
membesarkan rongga dada sehingga semakin besar oksigen yang masuk ke dalam paru, dengan demikian kapasitas vital paru akan meningkat dan alveoli juga akan berkembang semakin besar dan banyak (Kahar, 2017). Penyelam Freediving profesional saat ini, dapat melakukan penyelaman lebih lama karena telah mempersiapkan diri dengan menambah aktivitas aerobik dalam program latihannya.

Aktivitas fisik yang bisa dilakukan untuk menambah kapasitas vital paru yang disarankan adalah aktivitas yang berlangsung lama seperti jogging, maraton dan bersepeda jarak jauh (Giriwijoyo, 2017). Dalam penelitian Femilia Kahar (2017) (Kahar, 2017), terjadi peningkatan kapasitas vital paru pada pelajar sebelum $(2680,53 \mathrm{ml})$ dan setelah $(2947,37 \mathrm{ml})$ melakukan jogging selama 3 minggu. Selain jogging, berenang juga menambah kapasitas vital paru. Ketika berenang, tubuh terendam di dalam air di mana tekanan di dalam air lebih besar daripada tekanan di udara, dan juga semakin dalam kedalaman air maka tekanan akan semakin besar (West, 1999) sehingga hambatan bagi otot intercosta external untuk berkontraksi lebih besar dibandingkan dengan di darat (lingkungan udara). Latihan-latihan tersebut juga harus diimbangi dengan asupan gizi yang tepat. Asupan karbohidrat yang tidak tepat telah terbukti mengurangi durasi apnea, karena $\mathrm{CO}_{2}$ dihasilkan lebih cepat, penelitian ini dilakukan pada subjek yang telah berpuasa selama 18 jam dan menunjukan bahwa menyelam dengan perut kosong mungkin sangat berbahaya untuk dilakukan (Lindholm \& Lundgren, 2009).

Kapasitas vital paru juga dipengaruhi oleh faktor lain seperti jenis kelamin, usia, berat badan, tinggi badan, pola hidup, lingkungan, dan faktor keturunan atau genetik (Sherwood, 2015). Selain itu, daya serap oksigen maksimal $\left(\mathrm{VO}_{2} \mathrm{Max}\right)$ diduga juga berpengaruh terhadap kemampuan apnea. VO2max yang besar berarti daya serap oksigen per kilogram berat badan juga besar yang mengakibatkan tubuh lebih boros dalam penggunaan oksigen. $\mathrm{VO}_{2} \mathrm{Max}$ yang besar berpotensi menyebabkan durasi apnea menjadi lebih singkat karena oksigen lebih cepat habis. Hal ini mungkin perlu diperhatikan oleh para penyelam Angkatan Laut yang program pelatihannya sejak pendidikan pertama (DIKMA) terbukti dapat meningkatkan $\mathrm{VO}_{2} \mathrm{Max}$ dengan signifikan (Putra \& Haridito, 2013), sehingga diharapkan Angkatan Laut dapat menentukan personel yang tepat untuk melakukan sebuah operasi bawah air. Namun penelitian lebih lanjut masih diperlukan untuk memastikan teori tersebut. Durasi apnea juga mungkin berkaitan dengan jumlah hemoglobin dan eritrosit dalam darah. Karena oksigen diangkut oleh hemoglobin dalam eritrosit maka diduga ada kaitannya dengan kemampuan apnea. Namun studi lebih lanjut juga perlu dilakukan.

Jika seorang freediver ingin meningkatkan kemampuannya dalam menahan nafas, maka sangat penting untuk memperhatikan variabel-variabel yang berkaitan dengan suplai oksigen. Latihan intensitas tinggi seperti High Intensity Interval Training (HIIT), mungkin kurang disarankan bagi freediver karena dapat meningkatkan $\mathrm{VO}_{2} \mathrm{Max}$ dan hemoglobin (Putra, Al Ardha, Kinasih, \& Aji, 2017) sehingga berdampak pada cepat habisnya cadangan oksigen dalam paru dan darah. Selain itu freediver juga perlu memperhatikan pola gerak dan kekuatan gerak tubuhnya. Kontraksi otot yang kuat akan memicu jantung berdenyut lebih cepat sehingga transpor oksigen dan karbondioksida berlangsung lebih cepat pula. Studi lebih lanjut diperlukan untuk mempelajari variabel-variabel terkait transpor oksigen dan kerja otot untuk menemukan korelasinya dengan kemampuan apnea pada freediver.

\section{Simpulan dan Rekomendasi}

Hasil penelitian ini menyimpulkan bahwa kapasitas vital paru memiliki korelasi positif yang kuat dengan durasi apnea. Subjek dengan kapasitas vital paru yang besar dapat menahan nafas lebih lama dibandingkan dengan subjek yang memiliki kapasitas vital paru lebih kecil. Disarankan para freediver untuk meningkatkan kapasitas parunya dengan latihan-latihan yang bersifat aerobik. 


\section{Ucapan Terima Kasih:}

Terima kasih kami sampaikan kepada seluruh pihak yang telah berkontribusi dalam penelitian ini. Khususnya untuk laboratorium terpadu FKIK UKSW yang telah menyediakan sarana dan prasarana yang dibutuhkan untuk melaksanakan penelitian ini).

\section{Daftar Pustaka:}

AIDA-International. (1992). AIDA | Freediving. Retrieved March 26, 2020, from https://www.aidainternational.org/Freediving

Bosco, G., Rizzato, A., Moon, R. E., \& Camporesi, E. M. (2018). Environmental Physiology and Diving Medicine. Frontiers in Psychology, 9(FEB), 72. https://doi.org/10.3389/fpsyg.2018.00072

Butler, F. (2005). Breath-Hold Diving-A Proposed 60-second Rule. United State.

Cafaro, R. P. (1960). Hypoxia: Its Causes and Symptoms. Journal of the American Dental Society of Anesthesiology, 7(4), 4-8. Retrieved from http://www.ncbi.nlm.nih.gov/pubmed/19598857

Christen, O. (2015). Aida2 Freediving Manual. France.

Dahlan, M. S. (2015). Statistik untuk kedokteran dan kesehatan. Epidemiologi Indonesia. Jakarta.

Erez, B. (2016). Stage freediving enjoy the silence (B). Australia: Apnea International.

Giriwijoyo, H. Y. S. S. (2017). Fisiologi Kerja dan Olahraga. Jakarta: Rajawali Pers.

Guyton, A. C., \& Hall, J. E. (2006). Textbook of Medical Physiology (11th ed.). Philadelphia: Elsevier Inc.

Kahar, F. (2017). Pengaruh Latihan Aerobik.

Lindholm, P., \& Lundgren, C. E. (2009). The physiology and pathophysiology of human breath-hold diving. Journal of Applied Physiology, 106(1). Retrieved from http://jap.physiology.org/content/106/1/284.short

McArdle, W. D., Katch, V. L., \& Katch, F. I. (2009). Exercise Physiology: Nutrition, Energy, and Human Performance (7th ed.). United States: Lippincott Williams \& Wilkins.

Morris, J. F. (1976). Spirometry in the evaluation of pulmonary function. Western Journal of Medicine, 125(2), 110-118.

Ostrowski, A., Strzała, M., Stanula, A., Juszkiewicz, M., Pilch, W., \& Maszczyk, A. (2012). The role of training in the development of adaptive mechanisms in freedivers. Journal of Human Kinetics, 32, 197-210. https://doi.org/10.2478/v10078-012-0036-2

Pearn, J. H., Franklin, R. C., \& Peden, A. E. (2015). Hypoxic blackout: Diagnosis, risks, and prevention. International Journal of Aquatic Research and Education, 9(3), 342-347. https://doi.org/10.1123/ijare.2015-0036

Perlman, J. M. (2007). Pathogenesis of hypoxic-ischemic brain injury. Journal of Perinatology, 27(1), S39S46. https://doi.org/10.1038/sj.jp.7211716

Putra, K. P., Al Ardha, M. A., Kinasih, A., \& Aji, R. S. (2017). Korelasi Perubahan Nilai VO2Max, Eritrosit, Hemoglobin dan Hematokrit Setelah Latihan High Intensity Interval Training. Jurnal Keolahragaan, 5(2), 161-170.

Putra, K. P., \& Haridito, I. (2013). Pengaruh Program Pelatihan Fisik Militer Terhadap Peningkatan VO2Max Siswa Pendidikan Pertama Tamtama Tentara Nasional Indonesia Angkatan Laut. Jurnal Kesehatan Olahraga, 1(1). Retrieved from http://jurnalmahasiswa.unesa.ac.id/index.php/jurnalkesehatan-olahraga/article/view/1922

Schödel, J., \& Ratcliffe, P. J. (2019, October 1). Mechanisms of hypoxia signalling: new implications 


for nephrology. Nature Reviews Nephrology.
https://doi.org/10.1038/s41581-019-0182-z

Sewa, D. W., \& Ong, T. H. (2014). Pulmonary function test: Spirometry. Proceedings of Singapore Healthcare, 23(1), 57-64. https://doi.org/10.1177/201010581402300110

Sherwood, L. (2015). Fisiologi Manusia: Dari Sel ke Sistem. (D. R. Herman Octavius Ong, Albertus Agung Mahode, Ed.) (8th ed.). Jakarta: EGC.

West, J. B. (1999). The original presentation of Boyle's law. Journal of Applied Physiology, 87(4), 15431545. https://doi.org/10.1152/jappl.1999.87.4.1543. 